\title{
Unintentional, Unavoidable, and Beneficial Knowledge Leakage from the Multinational Enterprise
}

Inkpen, Andrew; Minbaeva, Dana; Tsang, Eric W. K.

\author{
Document Version \\ Accepted author manuscript \\ Published in: \\ DOI: \\ $10.1057 / s 41267-018-0164-6$ \\ Publication date: \\ 2019 \\ License \\ Unspecified
}

Journal of International Business Studies

Citation for published version (APA):

Inkpen, A., Minbaeva, D., \& Tsang, E. W. K. (2019). Unintentional, Unavoidable, and Beneficial Knowledge Leakage from the Multinational Enterprise. Journal of International Business Studies, 50(2), 250-260. https://doi.org/10.1057/s41267-018-0164-6

Link to publication in CBS Research Portal

\section{General rights}

Copyright and moral rights for the publications made accessible in the public portal are retained by the authors and/or other copyright owners and it is a condition of accessing publications that users recognise and abide by the legal requirements associated with these rights.

\section{Take down policy}

If you believe that this document breaches copyright please contact us (research.lib@cbs.dk) providing details, and we will remove access to the work immediately and investigate your claim.

Download date: 26. Apr. 2023
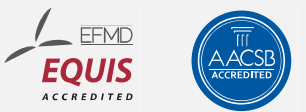


\section{Unintentional, Unavoidable, and Beneficial Knowledge Leakage from the Multinational Enterprise Andrew Inkpen, Dana Minbaeva, and Eric W. K. Tsang}

Journal article (Accepted version*)

\section{Please cite this article as:}

Inkpen, A., Minbaeva, D., \& Tsang, E. W. K. (2019). Unintentional, Unavoidable, and Beneficial Knowledge Leakage from the Multinational Enterprise. Journal of International Business Studies, 50(2), 250-260. 001: 10.1057\%2Fs41267-018-0164-6

This is a post-peer-review, pre-copyedit version of an article published in Journal of International Business Studies. The final authenticated version is available online at:

DOI: https://doi.org/10.1057\%2Fs41267-018-0164-6

* This version of the article has been accepted for publication and undergone full peer review but has not been through the copyediting, typesetting, pagination and proofreading process, which may lead to differences between this version and the publisher's final version AKA Version of Record.

Uploaded to CBS Research Portal: May २०19 


\title{
Unintentional, unavoidable and beneficial knowledge leakage from the multinational enterprise
}

\author{
Andrew Inkpen \\ Thunderbird School of Global Management \\ Arizona State University \\ 1 Global Place \\ Glendale AZ 85306 \\ USA \\ Tel: (602) 978-7079 \\ E-mail: andrew.inkpen@thunderbird.asu.edu \\ Dana Minbaeva \\ Copenhagen Business School \\ Kilevej 14, 2000 Frederiksberg \\ Denmark \\ Tel: (45) 38152527 \\ E-mail: dm.smg@cbs.dk \\ Eric W.K. Tsang \\ Naveen Jindal School of Management \\ University of Texas at Dallas \\ 800 W Campbell Rd., SM43 \\ Richardson, TX 75080-3021 \\ USA \\ Tel: (972) 883-4386 \\ Fax: (972) 883-6521 \\ E-mail: ewktsang@utdallas.edu
}

Forthcoming in the Journal of International Business Studies

Acknowledgement: We thank Wolfgang Sofka for helpful comments on the manuscript. 


\section{Biographical Sketches}

Andrew Inkpen is the J. Kenneth and Jeanette Seward Chair in Global Strategy at Thunderbird School of Management, Arizona State University. His research areas include global strategy, the management of multinational firms, the management of strategic alliances and international joint ventures. In recent years much of his research has focused on the global energy industry.

Dana Minbaeva is a Professor of Strategic and Global Human Resource Management at the Department for Strategic Management and Globalization, and the Vice-President for International Affairs at Copenhagen Business School. Her research focus is on strategic international HRM, knowledge sharing and transfer in multinational corporations. She received several national and international awards for research achievements and knowledge dissemination, including the prestigious JIBS Decade Award 2013.

Eric W. K. Tsang is the Dallas World Salute Distinguished Professor of Global Strategy at the Naveen Jindal School of Management, University of Texas at Dallas. He received his PhD from the University of Cambridge. His main research interests include organizational learning, strategic alliances, entrepreneurship, and philosophical analysis of methodological issues. 


\begin{abstract}
Knowledge leakage as an undesirable outcome for MNEs is an accepted view in IB literature. We challenge this view and argue that knowledge leakage is often unintentional, unavoidable and beneficial for the MNE. In a highly networked and information rich society, knowledge leakage from MNEs (1) happens naturally due to interfirm relationships, interactions and socialization, (2) is unavoidable due to employee mobility, and (3) facilitates knowledge inflows due to the reciprocity nature of knowledge exchange, and hence, is beneficial for MNEs. In addition, the costs of protecting knowledge incurred by an MNE will often outweigh the benefits.
\end{abstract}

Keywords: knowledge leakage, knowledge protection, reciprocity 


\section{Unintentional, unavoidable and beneficial knowledge leakage from the multinational enterprise}

The creation and transfer of knowledge is hailed as a basis for competitive advantage in firms (Argote $\&$ Ingram, 2000). Multinational enterprises' (MNEs') very existence is closely related to taking advantage of differences in knowledge and expertise around the world in terms of both exploiting existing repositories of knowledge and combining them to create new knowledge (Kogut \& Zander, 1993). While co-creating, sharing, and combining knowledge, MNEs may find that their knowledge leaks outside their firm boundaries. In this essay we argue that contrary to the generally accepted view in international business (IB) literature, knowledge leakage can be beneficial for the MNE. Rather than focusing on the cost of knowledge protection and the risk of knowledge leakage, MNEs should be assessing, and capitalizing on, the knowledge acquisition and creation opportunities associated with participating in knowledge exchanges across their value chain.

\section{Knowledge leakage}

Alerting managers to the risk of knowledge leakage, especially in the context of strategic alliances, IB literature has many examples of MNEs' alliance partners appropriating their valuable knowledge (Inkpen, 2000). An illustrative example is Kawasaki Heavy Industries' joint venture in China set up in 2005 to manufacture high-speed trains. In a press release Kawasaki described the objectives of the joint venture: "Kawasaki expects to sharpen its competitive edge and to increase its orders in the Chinese market by providing engineering expertise.... For the longer term, Kawasaki plans to enhance the businesses of the joint venture to include procurement of rail car parts within and outside of China" (Shirouzu, 2010). One of Kawasaki's partners, CSR Sifang Locomotive and Rolling Stock Co.. Ltd. introduced its own highspeed trains in China in 2010. According to Kawasaki, the Chinese partner illegally appropriated its technology based on its access to Kawasaki internal knowledge and intellectual property via the joint venture. If that is the case, Kawasaki was a victim of knowledge leakage - its proprietary knowledge 
being "intentionally appropriated by or unintentionally transferred to partners beyond the scope of the alliance agreement" (Jiang et al., 2013: 984).

Knowledge leakage is a fundamental dilemma of interfirm relationships (Heiman \& Nickerson, 2004). The literature on cross-border inter-firm collaboration warns about the risk of knowledge leakage when alliance partners act opportunistically (Hamel, 1991) or free-ride on their partners' innovative efforts (Oxley \& Sampson, 2004). Collaboration usually involves knowledge transfer, much of which may be difficult to legally protect from appropriation (Heiman \& Nickerson, 2004). Terms such as "reluctant loser" have been coined to describe the firm that loses out to its alliance partner's aggressive efforts to acquire its knowledge (Khanna, Gulati, \& Nohria, 1998). In the case of international joint ventures, Hertzfeld, Link and Vonortas's (2006) study of the effectiveness of intellectual property protection mechanisms used by U.S.-based companies in the formation of research partnerships concludes that "IP protection is a fundamental consideration for all research partnership members" (p. 836). MNEs may find themselves competing with domestic firms that are able to upgrade their skills, often by hiring MNE employees and copying marketing and distribution strategies. Research and development (R\&D), in particular, is one of the least internationalized MNE activities because firms fear that doing so will result in a loss of control over the innovation process and knowledge leakage to competitors (Berry, 2014).

Given the various admonitions in IB literature about MNEs' need to protect their knowledge from opportunistic partners, suppliers, and local competitors, it might seem reasonable to conclude that, from an MNE perspective, knowledge leakage is undesirable and must be prevented. This paper challenges this view and argues that knowledge leakage is often unintentional, unavoidable and can be beneficial for the $M N E$. Specifically, we argue that in any cross-border inter-firm collaboration knowledge leakage from MNEs happens naturally due to interfirm relationships, interactions and socialization. It is often unintentional, i.e. not done on purpose, and hence cannot be fully controlled. Instead, the firms should accept that some knowledge leakage is going to happen, carefully evaluate potential benefits of knowledge leakage, and design actions to minimize its costs. Our second point is that in a highly networked and information rich society, knowledge leakage is unavoidable due to employee mobility and 
hence cannot be prevented. Instead of engaging in defensive or regulatory actions for minimizing mobility, firms are encouraged to adopt a more strategic relational approach to employee mobility and get benefit from access to clients, access to new forms of human capital and opportunity to generate goodwill assets (Somaya \& Williamson, 2011). Finally, we argue that knowledge leakage facilitates knowledge inflows due to the reciprocity nature of knowledge exchange, and hence, is beneficial for MNEs. We also argue that the costs of knowledge protection incurred by an MNE will often outweigh the benefits.

Overall, we believe that the total outcomes for MNEs from knowledge leakages are positive, a position that is contrary to much of the IB literature on knowledge spillovers and leakage.

\section{Point 1. Knowledge leakage happens naturally in interfirm relationships}

Firms do not operate in isolation. Rather, they have to engage in transactions with other firms. Knowledge leakage may happen unintentionally and naturally when firms are involved in interfirm relationships, such as industry co-location and alliances, joint ventures, and partnerships.

Co-location as one form of interfirm relationship can occur in various ways. When firms are colocated in an agglomeration, such as in Silicon Valley or the financial districts of New York or London, there will be externalities from the agglomeration. One possible externality is knowledge leakage from one firm to another. Firms that are exposed to other co-located firms can capture new knowledge and improve products and processes, often at very little cost. In the field of regional studies one of the most established arguments is that knowledge-intensive activities are impacted from co-location due to frequent interactions, socialization, and access to labor (Grillitsch \& Nilsson, 2017).

It has been argued that when firms are clustered in an agglomeration those firms with inferior technology, human capital, training programs, suppliers, or distributors will substantially gain from the knowledge of the most successful firms (Alcácer \& Chung, 2007; Kalnins \& Chung, 2004; Shaver \& Flyer, 2000). The successful firms will gain little and could be hurt as knowledge leaks to their less successful competitors. Because the less successful firm, i.e. the firm with poor technology, process, and people, can greatly enhance its competitiveness through knowledge acquired from the more competitive 
firm, the poor technology firm will have a greater incentive to co-locate with other firms in its competitive set. For the stronger firm, one option is to remain isolated and not locate close to competitors and, in doing so, will prevent its knowledge from leaking to less well-endowed competitors.

The above co-location argument may be valid for industries such as semiconductors and biotechnology where success depends on a homogeneous set of technologies. It is not valid for some other industries or situations - for example, when the co-located firms represent a mix of firms from different countries, as in industrial clusters such as Silicon Valley or in the financial districts of New York, London, Frankfurt, Hong Kong and Tokyo. The knowledge stocks of firms are heterogeneous, as co-location researchers usually acknowledge. No firm will have a uniquely strong knowledge base across the entire industry value chain. Heterogeneity becomes even more apparent in an IB environment where firms from different countries and cultures co-locate. In this scenario there are knowledge acquisition opportunities for multiple firms, not just the low resource firms. Moreover, the knowledge flows will happen naturally as firms interact, compete, and establish themselves within the agglomeration of firms.

In addition to knowledge leakage associated with agglomeration, knowledge leakage is highly likely for firms in alliances and partnerships. There is an extensive literature examining knowledge flows between alliance partners, with substantial focus on the risks of unwanted opportunism by one partner and involuntary leakage of technology, skills, or other types of private knowledge (Ding, Huang, \& Liu, 2012; Gulati \& Singh, 1998; Inkpen, \& Beamish, 1997; Kale, Singh, \& Perlmutter, 2000; Madhok \& Tallman, 1998). In the opportunism scenario, one firm appropriates the knowledge of another without compensation, thus harming the originator firm.

Although knowledge leakage may lead to negative outcomes for the partner whose knowledge is unwillingly misappropriated, our contention is that this is a somewhat rare event. Knowledge leakage from one alliance partner to another will usually occur if the interfirm relationship involves interaction between managers from the partners. Consider the following example. In the oil and gas industry there are many alliances formed between international oil companies like ExxonMobil and Shell and national oil companies (NOCs) owned or controlled by state governments. In countries with abundant oil and gas 
resources, NOCs are the vehicle through which the resources can be managed and monetized. In a typical arrangement, an NOC will partner with an international oil company to produce the in-country oil or gas. The partnerships are structured in a variety of ways. A common thread is that in the early years of the project the international oil company provides the technology and managerial capabilities necessary to produce oil and gas, with income from oil production shared between the partners. The international oil company will typically second a set of experienced engineers and managers to the partnership, which brings the risk of knowledge leakage to the partner and local country. As an example, Petronas - the NOC of Malaysia - was established in 1974 with 15 employees and a small office in Kuala Lumpur. Over the subsequent decades international oil companies such as ExxonMobil, Hess, Murphy, Shell, and Talisman partnered with Petronas to produce Malaysian oil and gas. In 1991 Petronas launched its first international venture in Vietnam and in 1998 discovered oil in offshore Vietnam. In 2017 Petronas operated in 35 countries and competed in the upstream, refining, lubricants, and petrochemicals sectors. Had Petronas not had exposure to the technologies and managerial skills of the international oil companies it is doubtful it could have become a legitimate international oil company in its own right. For the international oil companies the creation of an international competitor was a cost of entry into the Malaysian market. More importantly, knowledge gained by Petronas was probably the result of planned transfer by these international oil companies rather than unintended leakage due to Petronas' opportunistic behavior.

As the previous example shows, knowledge leakage that happens naturally in an interfirm relationship is not necessarily costless. Petronas used knowledge obtained from its international partners as a foundation for its international expansion. In doing so, Petronas became a potential competitor to its international oil company partners, which is a cost to these companies. The challenge for the Petronas partner is to assess the cost, probability and consequences of knowledge leakage. For companies involved in these types of relationships, the seemingly most rational decision is to exploit the opportunity of working with the local company. Giving up the opportunity will not prevent local companies like Petronas from partnering with other international companies, resulting in a similar path of knowledge 
development and lost business for the international company that chooses not to partner. In the alliance field the cost of knowledge leakage has been linked empirically with alliance scope (Oxley \& Sampson, 2004) and alliance form (Sampson, 2004). However, both studies have as their underlying foundation the argument that knowledge leakage is likely to occur and must be minimized because of its cost. The question of how executives involved in interfirm relationships evaluate the benefits and costs of knowledge leakage remains a topic for future empirical research.

\section{Point 2. Knowledge leakage is unavoidable due to employee mobility and social network embeddedness}

Most valuable knowledge resides in individuals (Grant, 1996) and individuals move within and between firms, industries, and countries. Employee mobility is "a key driver of knowledge diffusion across existing organizations" (Ganco, 2013: 668). With growing employee mobility in the future there will be an increase in knowledge flows between firms. The strategic management literature presents solid evidence that intra-industry mobility (i.e., individuals moving from one firm to another in the same industry) is a powerful engine of knowledge diffusion between firms and even amongst rivals (Almeida \& Kogut, 1999). Studies in entrepreneurship confirm that employee mobility generates knowledge flows (Kim \& Steensma, 2017). Even contingent workers (e.g. freelancers, independent contractors, consultants) can be a medium through which a firm's proprietary knowledge is leaked to other organizations (Matusik \& Hill, 1998).

With increased labor market dynamism, growing employee mobility, rising trends of job hopping and boundaryless careers, knowledge leakage becomes unavoidable. This is especially true in the context of emerging markets and, specifically, in the areas of foreign direct investment (FDI) concentration, in which we observe strong competition for scarce human capital. For example, in the Moscow and St. Petersburg regions of Russia, the number of qualified candidates - those with diploma from a recognisable university, knowledge of foreign languages, additional functional training and work experience - is limited (less than $20 \%$ of all candidates on the labour market). Hence, a qualified 
candidate may have two or three offers at the same time from both domestic and foreign firms. Fuelled with emerging collective-oriented materialism (Awanis, Schlegelmilch \& Cui, 2017) and increases in the strength of certain "needs" (usually those which emphasize status and achievement), the norm of employees spending whole careers within one or two firms is becoming obsolete (Morley, Minbaeva, \& Michailova, 2016). Qualified candidates move within and between industries and switch between domestic and foreign firms. Entrepreneurial individuals may leave their employers, set up their own firms, and hire the initial workforce from former employers (Cheyre, Klepper, \& Veloso, 2014). These movements typically also involve transfer of skills and knowledge.

Moreover, mobility and associated with it knowledge leakage increases with the growth in quality of local human capital. Regardless of location and country of origin, many companies continuously invest in training and development, support individuals' quest for lateral transfer, and strive to provide adequate opportunities for professional growth and career advancement (so called convergence of human resource practices, see Pudelko \& Harzing, 2007). The labor economics literature shows that the mobility of trained employees compared to non-trained employees is higher (Becker, 1964). Finally, Sofka, Preto and de Faria (2014) introduce displacement as another channel for flows of human capital and knowledge between MNE subsidiaries and local firms. When an MNE closes a subsidiary, it voluntarily makes people with various knowledge and skills available to the market, which could include competitors. With subsidiary closures occurring more frequently (Berry, 2013), there will be a leakage of knowledge, skills and other valuable strategic assets to host-country rivals.

In addition to employee mobility, knowledge leakage is unavoidable due to the informal networks in which individuals are embedded. MNE subsidiaries are members of local business networks in their host countries (Andersson, Forsgren, \& Holm, 2002), and their employees are embedded in local social networks and knowledge sharing communities (Minbaeva \& Santangelo, 2018). From an MNE perspective, such multiple embeddedness is desirable and has positive performance implications (Meyer, Mudambi, \& Narula , 2011). Managers and technical personnel, such as engineers and R\&D scientists, frequently provide information or advice to colleagues in other firms. Individuals meet at conferences or 
annual meetings of professional associations. They are alumni of the schools and colleges they previously attended, and have friends, neighbors, and relatives. In short, they are deeply embedded in various social networks. When they encounter a problem at the workplace that they cannot solve, it is natural that they call on each other for help and activate their networks to exchange information (Bouty, 2000). Thus, multiple embeddedness creates informal communication networks that often constitute an important channel for distributing information among firms, including firms that compete in the same industry (Schrader, 1991).

Since knowledge leakage is unavoidable, solely focusing on its negative outcomes may not be helpful. Supplementing the argument that employee mobility will increase knowledge leakage, our view is that mobility and the associated knowledge flows will have overall positive outcomes. Indeed, human capital mobility scholars suggest that instead of framing employee mobility as a win-lose scenario in which firms are competing in a war for talent, a relational approach to mobility should be used. Companies would be better served by adopting a more holistic perspective: rather than viewing employee mobility as a risk for knowledge leakage, companies should leverage the potential opportunities created by employee mobility (Minbaeva \& Collings, 2013; Somaya \& Williamson, 2011; Somaya, Williamson, \& Lorinkova, 2008). In this situation, the key for organizations is to carefully monitor mobility in terms of its impact on performance, difficulty of replacement and destination employer (competitor versus "cooperator"). If employees leave to join a co-operator, there may be significant merit in maintaining relationships with those employees. For example, a number of major consulting firms (e.g. McKinsey) make significant investments in alumni networks with the explicit aim of maintaining links, building potential working relationships with the new firms and exchanging knowledge. A recent study of new ventures found that losing employees to new ventures could potentially provide incumbent firms with avenues through which to attain the new venture knowledge that they need to thrive (Kim \& Steensma, 2017). 


\section{Point 3. Knowledge leakage facilitates inflows due to the norm of reciprocity}

A major knowledge imperative of many MNE subsidiaries is to innovate and create useful knowledge. Yet knowledge creation is a complex task that a subsidiary can hardly accomplish in isolation, and often depends on the subsidiary's ability to acquire knowledge from external sources and recombine it with internal knowledge (Laursen \& Salter, 2006; von Hippel, 1988). Domestic firms in the host countries where MNE subsidiaries are located constitute a crucial source of knowledge. Moreover, local sources of knowledge are often complementary to, or at least non-redundant with, the internal pools of knowledge accessed by subsidiaries (Singh, 2008). Empirical studies show that subsidiaries do extensively source knowledge from host countries (e.g., Awate, Larsen, \& Mudambi, 2015; Colakoglu, Yamao, \& Lepak, 2014; Singh, 2007). However, acquiring knowledge from the external environment is not an automatic process after a subsidiary has been set up in a host country. Interfirm and interpersonal linkages have to be established through repeated interactions, which often take place informally and haphazardly without any explicit agreement between the firms involved (Almeida \& Phene, 2004).

In such situations, a usual concern of MNE subsidiaries is the need for knowledge protection at the subsidiary level. MNEs have different measures to protect their propriety knowledge, which can be broadly classified as formal or strategic (de Faria \& Sofka, 2010). For strategic protection measures, stringent measures guarding against knowledge leakage may hinder absorption of external knowledge. In particular, in certain industries it is undesirable for a firm to strictly control knowledge-trading with outsiders, who can absorb and appropriate the firm's knowledge but at the same time may possess knowledge that is highly valuable to the firm and would take the firm substantial time and resources to develop on its own (Liebeskind, 1997). Monteiro, Mol and Birkinshaw (2017) studied responses from 12,152 firms to the fourth and fifth UK versions of the Community Innovation Survey. Their results indicate that the use of secrecy negatively moderates the positive effects of openness to external knowledge on innovation performance (measured in terms of innovation output and the percentage of revenues deriving from new products). The use of secrecy as a protection measure is a double-edged sword: "it helps to protect existing knowledge assets, but is actually damaging to the firm's ability to 
enjoy innovation benefits from its relationships with external firms" (Monteiro et al., 2017: 283). Secrecy sends a signal to the firm's external partners that it is not fully committed to share and develop knowledge together with them. Picking up the signal, these partners would hesitate to provide the knowledge the firm needs. The resulting relationships lack trust and are not conducive to knowledge exchange. Thus Monteiro et al. (2017) argue that since knowledge exchange and the notion of secrecy represent competing mindsets there is necessarily a tradeoff between the two.

Studies of how MNEs protect their knowledge show evidence of reciprocity. For example, de Faria and Sofka's (2010) study of MNE subsidiaries in Portugal and Germany found that MNEs choose a broader set of knowledge protection measures in a host country that has fewer opportunities for knowledge sourcing (such as Portugal), and that they opt for a narrower set of measures if they actively engage in innovation activities in a technology-rich host country (such as Germany). They argue that the latter case necessitates reciprocity in knowledge exchanges in order to fully benefit from host country knowledge flows. In another study, Perri and Andersson (2014) conducted an analysis of patent citation data on a sample of US subsidiaries of European and Asian firms in the semiconductor industry. Their results indicate that subsidiaries sourcing more from the external knowledge community are also more likely to contribute their knowledge to the community, again showing the mechanism of reciprocity in knowledge exchanges at work. To disentangle correlation from causality, they measured knowledge inflows in the three years prior to knowledge outflows. Yet, as admitted by the authors, their study has the usual limitations associated with patent data analysis, such as patents representing only the codified part of technology and failing to capture certain knowledge-related activities.

As first developed by Gouldner (1960), the norm of reciprocity states that "what one party receives from the other require(s) some return, so that giving and receiving are mutually contingent" (p. 169). This behavioral norm is clearly illustrated in the responses von Hippel (1987: 295) collected in his case study of the mini-mill industry: "Bayou Steel: 'How much is exchanged depends on what the other guy knows - must be reciprocal'. Chaparral Steel: 'If they don't let us in [to their plant] we won't let them in [to ours] - must be reciprocal'." Interestingly, Teigland and Wasko's (2003) study indicates that 
while knowledge can be sourced from coworkers within the same organizational unit without expectation of reciprocity, once physical organizational boundaries are crossed, expectations of returns for knowledge sharing come into play even between organizational units. As a further example, Cassiman and Veugelers (2002) studied R\&D cooperation among manufacturing firms in Belgium and found that when firms regard external information sources as important inputs to their innovation process, they are more likely to actively engage in cooperative $R \& D$ agreements, which grant, to a varying extent, $R \& D$ partners access to their knowledge. In other words, firms are willing to accept certain vulnerabilities on disclosing valuable knowledge if they expect to gain some knowledge in return. From a more strategic perspective, a firm may selectively reveal its knowledge to its peers in order to initiate collaborative relationships or influence the trajectory of technological development to its favor (Alexy, George, \& Salter, 2013).

At the individual level, the norm of reciprocity constitutes the bedrock of a trusting relationship. Accepting the vulnerabilities of disclosing knowledge helps to establish a sense of trust between information traders. Increased levels of trust facilitate knowledge sharing and alleviate the risk of opportunism, such as improper use of knowledge acquired by a network member. Norms of reciprocity and trust in turn give rise to social control, which is "a binding agent providing both the freedom and the control necessary for collaboration" (Larson, 1992: 91). Repeated knowledge exchanges are embedded in social networks such that "[i]ndividual aggressiveness is curbed by the prospect of ostracism among peers, in both trade and social circumstances" (Williamson, 1975: 107-108). Network members are able to recognize those who do not act cooperatively. Therefore, network members' opportunistic inclination impairs their ability to interact with other members (Reagans \& McEvily, 2003). Individual concerns over reputation, which is time consuming to establish but can be destroyed overnight, and the prospect of collective sanctions help to curtail opportunistic behaviors (Jones, Hesterly, \& Borgatti, 1997). As principals of their employees, firms prefer not to associate with individuals whose reputations are in jeopardy, providing an extra layer of control. In brief, although informal information trading is not governed by legal contracts, its risk may not be as high as sometimes perceived. 
To conclude, except in the highly unlikely scenario that MNE subsidiaries prefer isolation and decide to withdraw from any knowledge exchange with other firms in their host countries, it is not wise to impose strict measures that guard against knowledge leakage. By allowing pieces of their proprietary knowledge to leak to domestic firms, subsidiaries may develop a reputation for cooperation that generates reciprocity dynamics, which in turn facilitate the access to local sources of knowledge. The more subsidiaries share their expertise with domestic partners, the more likely they will successfully acquire useful knowledge in return (Perri \& Peruffo, 2016). A caveat is that as mentioned, such knowledge exchange often takes place informally. As such, MNE subsidiaries have to accept the uncertainty with respect to the knowledge they may receive in return for the knowledge they leak. This is a necessary risk that every party involved in such knowledge sharing activities has to bear.

\section{Is knowledge protection a solution?}

The IB literature's predominant view has been that knowledge leakage has negative consequences and, therefore, MNEs should take steps to protect their knowledge from leaking (e.g., Li et al., 2008; Oxley \& Sampson, 2004). This view has made its way into the business community. A thriving consulting industry has developed around the area of intellectual property protection. Intellectual property protection has been called the number one challenge for MNEs operating in China (Schotter \& Teagarden, 2014). Stories and case studies (Shih \& Wang, 2013) about joint venture partners, suppliers, and other firms stealing knowledge can lead MNE managers to a knee-jerk reaction that they have to avoid knowledge leakage at all costs.

We acknowledge the need to ensure that valuable knowledge and intellectual property is not lost to rivals. Unintended leakage of knowledge can lead to the creation of competitors and real value destruction may occur. However, knowledge protection also has costs. Devices, processes, and methods that are used to prevent knowledge leakage often can also hinder knowledge transfer (Easterby-Smith, Lyles, \& Tsang, 2008). The overly protective firm may struggle to find partners and firms to work with, which can become a major liability in a networked world. Excessive protection could lead to an MNE's 
unwillingness to cross borders or an aversion to taking investment and partnering risks that less protective firms are willing to take. Firms that focus on protection could be wasting resources on knowledge protection that would better be used to innovate and stay ahead of competition. Rather than focusing on protection firms should look for knowledge creation opportunities through their networking interactions with other firms. When Toyota established its first plant in North America in partnership with General Motors, Toyota chose to openly share knowledge with its partner (Inkpen, 2008). Toyota did not see protection as necessary given its strength in the automobile industry and its long-term goal of expanding beyond the initial market entry venture.

Knowledge protection is often not effective enough. Patenting is the most prominent form of formal protection measures and there are significant costs associated with its preparation and filing, which is often a time-consuming process. Moreover, the effectiveness of patenting is not guaranteed. For instance, $R \& D$ managers in the semiconductor industry consistently reported that "patents were among the least effective mechanisms for appropriating returns to R\&D investments" (Hall \& Ziedonis, 2001: 102). Worse still, litigation costs associated with patent infringement are often substantial (Lerner, 1995), as attested by the patent litigations engaged by Apple with various companies (Duhigg \& Lohr, 2012). Small firms are not likely to have the required financial resources to participate in such litigations even if their patents are clearly infringed. Such firms have to be very selective in patenting their inventions. Moreover, contrary to conventional wisdom in the innovation literature that patents promote technological progress, Takalo and Kanniainen's (2000) theoretical model shows that by reducing the risk of rivals' entry, patents enhance the ability of firms to wait for commercialization and, thus, may delay market introduction of innovative products. This in turn would hinder further technological progress, giving rise to considerable social cost.

Knowledge protection may be costly in other ways. Liebeskind (1997) discusses in detail various rules (e.g., restricting social interaction by specified employees with outsiders) that firms impose and enforce on their employees for knowledge protection. Such rules often come with significant costs, the most obvious of which is the cost of monitoring the rules. For instance, Rich and Janos (1994) document 
the high personnel costs of security monitoring during the process of producing the Stealth Fighter, a top secret weapon, by Lockheed Martin. Employees may react negatively to monitoring mechanisms that are perceived as invading their personal privacy (Kupfer, 1987), resulting in reduced trust and loyalty toward their organizations. Poor employee morale is not conducive to establishing an innovative organization. Further, rules that restrict information exchange and communication also work against a fundamental principle of innovation - open dialogue and critique of new ideas. In addition, it is difficult to identify protection rules that are effective. It is virtually impossible, for example, for the management of a hightech firm to formulate rules that dictate which external collaborations or exchanges that its scientists should, or should not, participate in. Residual leakage is therefore unavoidable. It is no wonder that Liebeskind (1997: 653) arrives at the central conclusion that "keeping organizational secrets is both difficult and costly."

\section{Conclusion}

MNEs exist to share and move knowledge around and between various subsidiaries. In doing so, firms engage with partners, suppliers, customers and competitors, exposing themselves to the potential that other firms will appropriate their valuable knowledge in a manner that leads to negative outcomes for the MNE. The potential for knowledge leakage is a function of several knowledge conditions that must be present: the MNE's most valuable knowledge is simple and fully codified (Coca-Cola's secret formula being a classic example); the MNE has employees who are highly mobile and motivated to seek new employers; and the MNE has low expectations of finding valuable knowledge outside its firm boundaries. Yet the existence of all these conditions in any one MNE is rare. Moreover, an MNE's valuable knowledge is usually complex and tacit; any single part of that knowledge is of little value in isolation. In order for the knowledge to generate competitive advantage in international markets, co-specialized and complementary assets (e.g., dedicated employees, brands, and distribution systems) must be linked with that knowledge (Teece, 2014). Leaking bits and pieces of the knowledge to competitors is usually of little 
consequence. ${ }^{1}$ Thus, in our view, the fear of knowledge leakage is often overstated, leading firms to resort to excessive protection and overly cautious behavior with respect to interactions with other firms.

Our arguments suggest several avenues for future research. Researchers need to revisit the assumption, which underpins many empirical studies, that knowledge leakage is harmful to MNEs. There are several specific questions that should be addressed, including: What are the positive outcomes of leakage for the MNE? Under what conditions and how might leakage improve performance? Are there specific types of knowledge leakage that lead to more positive outcomes? Are there certain types of MNEs that have to be more aware of the risks of knowledge leakage than others? When entering crossborder inter-firm collaborations, do executives consciously assess the degree of danger and consequences of knowledge leakage and if so how? How can MNEs strategically use knowledge leakage as a means of obtaining useful knowledge from domestic firms in a host country? How should the costs of a knowledge protection measure be identified (and, if possible, estimated) and compared with the supposed benefits of the protection?

Finally, our position on knowledge leakage has managerial implications, which we summarize as follows. First, given that knowledge leakage is often unintentional and unavoidable, firms should proactively assess the benefits, costs, and consequences of leakage rather than adopting the erroneous view that knowledge leakage is always a negative outcome. Second, when knowledge leakage is unavoidable and inevitable, firms should shift from a win-lose mentality towards a relational approach that leverages opportunities in areas such as employee mobility. Third, in return for revealing knowledge to peers, firms will often be able to initiate collaborative relationships or reciprocal exchanges of valuable knowledge. Fourth, knowledge protection has costs that may exceed the benefits of the protection. 


\section{References}

Alcácer, J., \& Chung, W. 2007. Location strategies and knowledge spillovers. Management Science, 53(5): 760-776.

Alexy, O., George, G., \& Salter, A. J. 2013. Cui bono? The selective revealing of knowledge and its implications for innovative activity. Academy of Management Review, 38(2): 270-291.

Almeida, P., \& Kogut, B. 1999. Localization of knowledge and the mobility of engineers in regional networks. Management Science, 45(7): 905-917.

Almeida, P., \& Phene, A. 2004. Subsidiaries and knowledge creation: The influence of the MNE and host country on innovation. Strategic Management Journal, 25(8-9): 847-864.

Andersson, U., Forsgren, M., \& Holm, U. 2002. The strategic impact of external networks: Subsidiary performance and competence development in the multinational corporation. Strategic Management Journal, 23(11): 979-996.

Argote, L., \& Ingram, P. 2000. Knowledge transfer: A basis for competitive advantage in firms. Organizational Behavior and Human Decision Processes, 82(1): 150-169.

Awanis, S., Schlegelmilch, B., \& Cui, C. 2017. Asia materialists: Reconciling collectivism and materialism. Journal of International Business Studies, 48(8): 964 - 991.

Awate, S., Larsen, M. M., \& Mudambi, R. 2015. Accessing vs sourcing knowledge: A comparative study of R\&D internationalization between emerging and advanced economy firms. Journal of International Business Studies, 46(1): 63-86.

Becker, G. 1964. Human capital. New York: Columbia University Press.

Berry, H. 2013. When do firms divest foreign operations? Organization Science, 24(1): 246-261.

Berry, H. 2014. Global integration and innovation: Multicountry knowledge generation within MNEs. Strategic. Management Journal, 35(6): 869-890.

Bouty, I. 2000. Interpersonal and interaction influences on informal resource exchanges between R\&D researchers across organizational boundaries. Academy of Management Journal, 43(1): 50-65.

Cassiman, B., \& Veugelers, R. 2002. R\&D cooperation and spillovers: Some empirical evidence from Belgium. American Economic Review, 92(4): 1169-1184.

Cheyre, C., Klepper, S., \& Veloso, F. 2014. Spinoffs and the mobility of U.S. merchant semiconductor inventors. Management Science, 61(3): 487-506.

Colakoglu, S., Yamao, S., \& Lepak, D. P. 2014. Knowledge creation capability in MNE subsidiaries: Examining the roles of global and local knowledge inflows and subsidiary knowledge stocks.

International Business Review, 23(1): 91-101.

de Faria, P., \& Sofka, W. 2010. Knowledge protection strategies of multinational firms - A cross-country comparison. Research Policy, 39(7): 956-968. 
Ding, X. H., Huang, R. H., \& Liu, D. L. 2012. Resource allocation for open and hidden learning in learning alliances. Asia Pacific Journal of Management, 29(1): 103-127.

Duhigg, C., \& Lohr, S. 2012. The patent, used as a sword. New York Times, October 7. [http://www.nytimes.com/2012/10/08/technology/patent-wars-among-tech-giants-can-stiflecompetition.html]

Easterby-Smith, M., Lyles, M.A., \& Tsang, E.W.K., 2008. Inter-organizational knowledge transfer: Current themes and future prospects. Journal of Management Studies, 45: 677-690.

Ganco, M. 2013. Cutting the Gordian knott: The effect of knowledge complexity on employee mobility and entrepreneurship. Strategic Management Journal, 34(6): 666-686

Gouldner, A. W. 1960. The norm of reciprocity: A preliminary statement. American Sociological Review, 25(2): 161-178.

Grant, R. M. 1996. Toward a knowledge-based theory of the firm. Strategic Management Journal, 17(special issue): 109-122.

Grillitsch, M., \& Nilsson, M. 2017. Firm performance in the periphery: On the relation between firminternal knowledge and local knowledge spillovers. Regional Studies, 51(8): 1219-1231.

Gulati, R., \& Singh, H. 1998. The architecture of cooperation: Managing coordination and appropriation concerns in strategic alliances. Administrative Science Quarterly, 43: 781-814.

Hall, B. H., \& Ziedonis, R. H. 2001. The patent paradox revisited: An empirical study of patenting in the US semiconductor industry, 1979-1995. RAND Journal of Economics, 32(1): 101-128.

Hamel, G. 1991. Competition for competence and inter-partner learning within international strategic alliances. Strategic Management Journal, 12(special issue): 83-104.

Heiman, B. A., \& Nickerson, J. A. 2004. Empirical evidence regarding the tension between knowledge sharing and knowledge expropriation in collaborations. Managerial and Decision Economics, 25(6-7): 401-420.

Hertzfeld, H. R., Link, A. N., \& Vonortas, N. S. 2006. Intellectual property protection mechanisms in research partnerships. Research Policy, 35(6): 825-838.

Inkpen, A. C. 2000. Learning through joint ventures: A framework of knowledge acquisition. Journal of Management Studies, 37(7): 1019-1043.

Inkpen, A. C. 2008. Knowledge transfer and international joint ventures: The case of NUMMI and General Motors, Strategic Management Journal, 29(4): 447-453.

Inkpen, A. C., \& Beamish, P. W. 1997. Knowledge, bargaining power and international joint venture stability. Academy of Management Review, 22(1): 177-202.

Jiang, X., Li, M., Gao, S., Bao, Y., \& Jiang, F. 2013. Managing knowledge leakage in strategic alliances: The effects of trust and formal contracts. Industrial Marketing Management, 42(6): 983-991. 
Jones, C., Hesterly, W. S., \& Borgatti, S. P. 1997. A general theory of network governance: Exchange conditions and social mechanisms. Academy of Management Review, 22(4): 911-945.

Kale, P., Singh, H., \& Perlmutter, H. 2000. Learning and protection of proprietary assets in strategic alliances: Building relational capital. Strategic Management Journal, 21(3): 217-237.

Kalnins, A., \& Chung, W. 2004. Resource-seeking agglomeration: A study of market entry in the lodging industry. Strategic Management Journal, 25(7): 689-699.

Khanna, T., Gulati, R., \& Nohria, N. 1998. The dynamics of learning alliances: Competition, cooperation, and relative scope. Strategic Management Journal, 19(3): 193-210.

Kim, J. Y. R., \& Steensma, H. K. 2017. Employee mobility, spin-outs, and knowledge spill-in: How incumbent firms can learn from new ventures. Strategic Management Journal, 38(8): 1626-1645.

Kogut, B., \& Zander, U. 1993. Knowledge of the firm and the evolutionary theory of the multinational corporation. Journal of International Business Studies, 24(4): 625-645.

Kupfer, J. 1987. Privacy, autonomy, and self-concept. American Philosophical Quarterly, 24(1): 81-89.

Larson, A. 1992. Network dyads in entrepreneurial settings: A study of the governance of exchange relationships. Administrative Science Quarterly, 37(1): 76-104.

Laursen, K., \& Salter, A. 2006. Open for innovation: the role of openness in explaining innovation performance among UK manufacturing firms. Strategic Management Journal, 27(2): 131-150.

Lerner, J. 1995. Patenting in the shadow of competitors. Journal of Law and Economics, 38(2): 463-495.

Li, D., Eden, L., Hitt, M. A., \& Ireland, R. D. 2008. Friends, acquaintances, or strangers? Partner selection in R\&D alliances. Academy of Management Journal, 51(2): 315-334.

Liebeskind, J. P. 1997. Keeping organizational secrets: Protective institutional mechanisms and their costs. Industrial and Corporate Change, 6(3): 623-663.

Madhok, A., \& Tallman, S. B. 1998. Resources, transactions and rents: managing value through interfirm collaborations. Organization Science, 9(3): 326-39.

Matusik, S. F., \& Hill, C. W. L. 1998. The utilization of contingent work, knowledge creation and competitive advantage. Academy of Management Review, 23(4): 680-697.

Meyer, K. E., Mudambi, R., \& Narula, R. 2011. Multinational enterprises and local contexts: The opportunities and challenges of multiple embeddedness. Journal of Management Studies, 48(2): 235-52.

Minbaeva, D., \& Collings, D. 2013. Seven myths of global talent management. International Journal of Human Resource Management, 24(9): 1762-1776.

Minbaeva, D., \& Santangelo, G. 2018. Boundary spanners and knowledge sharing in MNE: The individual perspective. Global Strategy Journal, 8(2): 220-241.

Monteiro, F., Mol, M., \& Birkinshaw, J. 2017. Ready to be open? Explaining the firm level barriers to benefiting from openness to external knowledge. Long Range Planning, 50(2): 282-295. 
Morley, M., Minbaeva, D., \& Michailova, S. 2016. The transition states of Central and Eastern Europe and the former Soviet Union. In C. Brewster \& W. Mayrhofer (Eds.), Handbook of research in comparative human resource management (2nd ed.): 550-575. Cheltenham, England: Edward Elgar.

Oxley, J. E., \& Sampson, R. C. 2004. The scope and governance of international R\&D alliances. Strategic Management Journal, 25(8-9): 723-749.

Perri, A., \& Andersson, U. 2014. Knowledge outflows from foreign subsidiaries and the tension between knowledge creation and knowledge protection: Evidence from the semiconductor industry. International Business Review, 23(1): 63-75.

Perri, A., \& Peruffo, E. 2016. Knowledge spillovers from FDI: A critical review from the international business perspective. International Journal of Management Reviews, 18(1): 3-27.

Pudelko, M., \& Harzing, A. 2007. Country-of-origin, localization, or dominance effect? An empirical investigation of HRM practices in foreign subsidiaries. Human Resource Management, 46(4): 535-559.

Reagans, R., \& McEvily, B. 2003. Network structure and knowledge transfer: The effects of cohesion and range. Administrative Science Quarterly, 48(2): 240-267.

Rich, B. R., \& Janos, L. 2013. Skunk works: A personal memoir of my years of Lockheed. Boston, MA: Little Brown \& Company.

Sampson, R. C. 2004. Organizational choice in R\&D alliances: Knowledge-based and transaction cost perspectives. Managerial and Decision Economics, 25(6-7): 421-436.

Schotter, A., \& Teagarden, M. 2014. Protecting intellectual property in China. MIT Sloan Management Review, 55(4): 41-48.

Schrader, S. 1991. Informal technology transfer between firms: Cooperation through information trading. Research Policy, 20(2): 153-170.

Shaver, J. M., \& Flyer, F.. 2000. Agglomeration economies, firm heterogeneity, and foreign direct investment in the United States. Strategic Management Journal, 21(12): 1175-1193.

Shih, W., \& Wang, J. C. 2013. Will our partner steal our IP? Harvard Business Review, 91(1): 137-141.

Shirouzu, N. 2010. Train makers rail against China's high-speed designs. Wall Street Journal, November 17. [https://www.wsj.com/articles/SB10001424052748704814204575507353221141616]

Singh, J. 2007. Asymmetry of knowledge spillovers between MNEs and host country firms. Journal of International Business Studies, 38(5): 764-786.

Singh, J. 2008. Distributed R\&D, cross-regional knowledge integration and quality of innovative output. Research Policy, 37(1): 77-96.

Sofka, W., Preto, M., \& de Faria, P. 2014. MNE subsidiary closures: What is the value of employees' human capital in new jobs? Journal of International Business Studies, 45(6): 723-750. 
Somaya, D., \& Williamson, I. 2011. Embracing turnover: Moving beyond the "war for talent.” In D. Collings \& H. Scullion (Eds.), Global talent management: 74-86. New York: Routledge.

Somaya, D., Williamson, I., \& Lorinkova, N. 2008. Gone but not lost: The different performance impacts of employee mobility between cooperators versus competitors. Academy of Management Journal, 51(5): 936-953.

Takalo, T., \& Kanniainen, V. 2000. Do patents slow down technological progress? Real options in research, patenting, and market introduction. International Journal of Industrial Organization, 18(7): 1105-1127.

Teece, D. J. 2014. A dynamic capabilities-based entrepreneurial theory of the multinational enterprise. Journal of International Business Studies, 45(1): 8-37.

Teigland, R., \& Wasko, M. M. 2003. Integrating knowledge through information trading: Examining the relationship between boundary spanning communication and individual performance. Decision Sciences, 34(2): 261-286.

von Hippel, E. 1987. Cooperation between rivals: Informal know-how trading. Research Policy, 16(6): 291-302.

von Hippel, E. 1988. The sources of innovation. New York: Oxford University Press.

Williamson, O. E. 1975. Markets and hierarchies: Analysis and antitrust implications. New York: Free Press.

\footnotetext{
${ }^{1}$ We acknowledge a reviewer for suggesting the conditions and their rarity.
} 